\title{
Morten Larsen
}

\section{Fødevareministeriet: fra erhvervets forlængede arm til forbrugernes beskytter?}

\begin{abstract}
Da Fødevareministeriet blev oprettet i 1996, var det ud fra et ønske om at styrke forbrugernes position i et ministerium, hvis politik traditionelt har været anset for at være domineret af erhvervets interesser. Baggrunden for den opfattelse er det lukkede netværk omkring Landbrugs- og Fiskeriministeriet. Tidligere forskning har vist, at den reelle effekt af reorganiseringer kan være til at overse, og mange spåede forbrugerne svære betingelser i det nye ministerium. I forbrugerpolitiske spørgsmål blev forbrugernes interesser imidlertid prioriteret højt, allerede før Fødevareministeriet blev dannet. Generelt har reorganiseringen således ikke haft den store betydning for varetagelsen af forbrugerinteresser. Udvidelsen af Fødevareministeriets kompetence til også at omfatte levnedsmiddelkontrol har dog medført, at forbrugerhensyn, som tidligere var undertrykt, nu er blevet opprioriteret. På trods af dette kommer den politiske opbakning ikke altid forbrugeme til gode.
\end{abstract}

Ved kongelig resolution af 30.12.1996 blev det besluttet, at betegnelsen for Landbrugs- og Fiskeriministeriet skulle ændres til Ministeriet for Fødevarer, Landbrug og Fiskeri (herefter Fødevareministeriet) (Fødevareministeriet, 1998: kap. 3: 1). Ved samme lejlighed fik Fødevareministeriet overført Levnedsmiddelstyrelsen fra Sundhedsministeriet og sager vedrørende ernærings- og levnedsmiddellovgivning. Endelig blev Levnedsmiddelstyrelsen 01.07.1997 lagt sammen med Veterinærdirektoratet i Veterinær- og Fødevaredirektoratet, senere Fødevaredirektoratet (Veterinær- og Fødevaredirektoratet, 1999b: kap. 2: 1). Ideen bag reorganiseringen var at samle kontrollen med fødevarer fra "jord til bord". Reorganiseringen og navneændringen af ministeriet skulle signalere, at ministeriet ikke længere udelukkende var et erhvervsministerium, men også et forbrugerministerium (Regeringen, 1998: 8; Kristensen, 1997: 101).

Ud fra det kunne man forvente, at forbrugerinteresser er blevet væsentligt opprioriteret som en følge af dannelsen af Fødevareministeriet. Men en ting er officielle politiske hensigter, noget andet er, hvad der rent faktisk er sket. Mange frygtede på forhånd, at forbrugerinteresserne ville blive klemt i et sådant ministerium. Henrik Dam Kristensen var dog ikke bekymret, da han anså forbruger- og producentinteresser for at være sammenfaldende, idet producenterne må tilbyde de varer, som forbrugerne ønsker. Han tilføjede dog også, "at der i konkrete sager let vil kunne forekomme tilfælde, hvor interesserne er modstående" (Kristensen, 1997: 100-101).

Opprioriteringen af forbrugerinteresser er derfor ikke så ligetil, som de politiske hensigter lægger op til. I visse sager vil forbrugerinteresser utvivlsomt møde modstand fra især landbruget og dets stærke interesseorganisationer. Netop denne problemstilling tages op af Carsten Daugbjerg (1999) i "Landbrugspolitik: Stabilitet eller forandring?". Daugbjerg beskæftiger sig primært med landbrugets ind- 
flydelse på dansk EU-landbrugspolitik, men behandler også betydningen af Fødevareministeriets dannelse. Her tegner han et billede af et ministerium, som generelt ikke har vist tegn på øget forbrugerbevidsthed (Daugbjerg, 1999: 119). Analysen hviler dog på et spinkelt grundlag. Der er derfor stadig brug for at belyse, hvorvidt dannelsen af Fødevareministeriet har ført til en opprioritering af forbrugerinteresser. Som nævnt er der på forhånd tegn, der peger i begge retninger.

Artiklens formål er således at undersøge, om dannelsen af Fødevareministeriet har ført til den tilsigtede opprioritering af forbrugernes interesser i forbrugerpolitiske spørgsmål. Definitionen af forbrugerinteresser tager udgangspunkt i politikkens formål. Forbrugerinteresser kan være mange ting afhængigt af område og er derfor svære at definere entydigt. Det afgørende vil være, om der er tale om tiltag, der søger at tilgodese forbrugerne.

Artiklen undersøger tre cases. Som optakt til case analyserne præsenteres de væsentligste aktører i de tre sager, herunder hvem der har fremført krav, der søger at tilgodese forbrugerne. Fokus er på den beslutningsforberedende fase i Fødevareministeriet. Her vil det blive analyseret, hvem der er blevet inddraget, hvornår de er blevet inddraget, og hvilke krav de har fremsat. Da der kan være forskel på inddragelse og reel indflydelse, skal forbrugerinteresser være medtaget $\mathrm{i}$ de udvalgte love, bekendtgørelser og kampagner, som Fødevareministeriet har forberedt, for at være blevet tilgodeset. ${ }^{2}$

\section{Teori og hypoteser om reorganisering og netværk}

Fødevareministeriet blev blandt andet dannet som en følge af Henrik Dam Kristensens $\emptyset$ nske om at styrke koordineringen og opprioritere forbrugerinteresser. Netop reorganisering kan være en måde at opnå politiske mål og hensigter (Winter, 1997; Christensen, 1987; Egebjerg, 1984). Ifølge det rationalistiske, instrumentelle perspektiv sker reorganiseringer ofte på baggrund af reelle hensigter om at påvirke det materielle indhold af den førte politik, typisk gennem en bedre målopnåelse eller en ændret politisk prioritering (Winter, 1987: 375). Tesen er dernæst, at formelle strukturer er afgørende for en organisations adfærd, og at offentlige institutioner kan designes til at forfølge specifikke mål. Perspektivet betoner, at "organization matters" (Scharpf, 1986: 179; 1977).

Denne teori fokuserer på den offentlige administration som et lukket system. I Danmark er der imidlertid stærke normer for at inddrage berørte interesseorganisationer, og forholdet til omgivelserne må derfor også inddrages (Christensen og Christiansen, 1997: 66). Dette samspil er blandt andet blevet beskrevet af Martin Smith (1993).

Med udgangspunkt i Smith kan staten, i dette tilfælde Fødevareministeriet, ses som en aktør, der har egne interesser, som godt kan være i modstrid med erhvervenes interesser. Staten indgår i netværk med omgivelserne, men Smith betoner, at magtforholdet mellem stat og interesseorganisationer er asymmetrisk. Det er i sidste ende staten, der skaber netværket, kontrollerer adgangen til netværket og skaber spillereglerne i netværket (Smith, 1993: 59). Staten kan altså ændre netværket, hvis den virkelig ønsker det. 
Anvendt på Fødevareministeriet betyder det, at reorganiseringen kan ses som udtryk for et reelt ønske om politisk forandring, og at Fødevareministeriet har tilstrækkelig autonomi til at gennemføre disse forandringer. Såvel det rationalistiske, instrumentelle perspektiv som netværksteorien kan derfor underbygge den første hypotese om, at der må forventes at være sket en opprioritering af forbrugerinteresser efter dannelsen af Fødevareministeriet i overensstemmelse med de politiske hensigter.

Der er imidlertid ikke enighed om betydningen af reorganiseringer og deres effekt. Andre forskere ser reorganisering som et politisk spil, der sjældent gennemføres, og hvis de gennemføres, sjældent har de tilsigtede effekter (Winter, 1987; March og Olsen, 1983; Scharpf, 1986). Det kan der være flere grunde til. Reorganiseringer kan tjene rent symbolske formål. Dette vil oftest være tilfældet, regeringen føler sig presset til at foregive at handle uden reelt at $\emptyset n$ ske det. Således beskriver Salamon (1981) for eksempel reorganiseringer som et alternativ til reel handling.

Ydermere er det sjældent, at der sker reelle ændringer, selv om de politiske motiver bag reorganiseringer er oprigtige. I disse tilfælde vil det oftest være et spørgsmål om "problem identified, but not solved" (March og Olsen, 1983: 288). En af grundene til dette er, at det er svært at fastholde den politiske bevågenhed på området. Derfor vil de aktører, der er involveret i netværket omkring ministeriet stille og roligt genindtage de dominerende roller, og disse har oftest en interesse i at undgå forandringer (Winter, 1987: 377). Endelig spiller det også en rolle, at ministeriets mulighed for at implementere sin politik vil blive væsentligt reduceret, hvis det lægger sig ud med de interesseorganisationer, som ellers bistår ministeriet med implementeringen (March og Olsen, 1983: 285).

Hvor svært det er at ændre de eksisterende forhold afhænger af, hvilke netværk ministeriet indgår i (jf. Rhodes og Marsh, 1992). Netop landbrugsområdet er blevet beskrevet som et af de områder, hvor interesseorganisationerne har det tætteste samarbejde med ministeriet og størst indflydelse på den førte politik (Daugbjerg, 1999; Just og Omholt, 1984; Buksti, 1983).

Det er primært interessekonfigurationen og landbrugets betydning for samfundsøkonomien, der ligger bag det tætte netværk. Wilson (1980) forudsiger, at der vil være størst chance for en effektiv mobilisering af interesser på områder, hvor der er koncentrerede interesser på spil, som det er tilfældet på landbrugsområdet (Winter, 1994: 33-34). Ydermere har landbruget og ministeriet arbejdet tæt sammen for at sikre gode eksportbetingelser og favorable vilkår i EF for dansk landbrug (Buksti, 1983: 16; Daugbjerg, 1999: 117). Samlet har det ført til dannelsen af et lukket netværk mellem landbrug og ministerium (Daugbjerg, 1999: 107; Christensen og Christiansen, 1997: 80)

Set i dette lys er det ikke overraskende, at Fødevareministeriet efter dets dannelse har været udsat for kritik. Forbrugerne er ikke med det samme blevet informeret om salmonella- og campylobacterfund, og nye EU-regler om medicinrester er ikke blevet videreformidlet. Blandt andet som en følge af dette har forbrugerrepræsentanter konkluderet, at landbrugsinteresser stadig har overtaget i det nye ministerium ("Skuffelse over ministerium", Jyllands-Posten, 26.07.1997; "Henrik Dam Kristensen i klemme i salmonellasag", Politiken, 22.07.1998; "Når tide- 
vandet stiger", Aktuelt, 25.07.1998; "Betændt sommer", Jyllands-Posten, 26.07.1998b).

På baggrund af de teorier, der generelt ser med skepsis på effekten af reorganiseringer, Wilsons overvejelser om interessekonfigurationers betydning samt det tætte samspil mellem landbrug og ministerium, kan den anden og konkurrerende hypotese præsenteres: landbruget har formået at bevare sin store indflydelse $i$ Fødevareministeriet, og som en følge heraf er forbrugerinteresser ikke blevet opprioriteret, hvor landbruget har modsat sig dette.

\section{De tre cases}

De re cases, der er inddraget, er fødevarekvalitetsmærket Den Blå Lup, Salmonellahandlingsplanen for konsumæg, og Kampagnen mod Vildledende Markedsføring. De tre cases er bevidst valgt, så de adskiller sig tidsmæssigt. Således lå størstedelen af det relevante arbejde med kvalitetsmærket før dannelsen af Fødevareministeriet i 1997 (Foreningen til Dyrenes Beskyttelse, 2000), arbejdet med salmonellahandlingsplanen foregik både før og efter 1997, og Vildledningskampagnen er fra perioden efter 1997. Dette skal give mulighed for at sammenligne situationen før Fødevareministeriets dannelse med situationen efter og derved vurdere, om der er sket en ændring.

I arbejdet med det nye fødevarekvalitetsmærke, symboliseret ved en blå lup omkranset af ordene "kvalitet med omtanke", har i alt 28 aktører været inddraget i udvalgsarbejdet med sagen (Veterinærdirektoratet, 1995a: 1). Det har derfor været nødvendigt at fokusere på de væsentligste. På forbrugersiden er det især Forbrugerrådet, Foreningen til Dyrenes Beskyttelse, Det Danske Gastronomiske Akademi og Eurotoques (de to sidstnævnte er sammenslutninger af kokke), der har søgt at tilgodese forbrugerinteresser ved at arbejde for et kvalitetsmærke, der inkluderede så mange $\mathrm{og}$ så skrappe krav som muligt. Denne politik har til formål at tilgodese forbrugerne, fordi det giver dem et mærke, der borger for kvalitet, og hvor der for eksempel ikke må anvendes antibiotiske vækstfremmere (Andresen, 1998: 558). Interessekonflikten har primært været med landbrugets og slagteriernes organisationer. ${ }^{3}$ Disse har været nervøse for, at for mange krav ville gøre produktionen af kødet for dyr og har derfor søgt at begrænse kravene til det nye kvalitetsmærke (Veterinærdirektoratet, 1995b: 5).

I udarbejdelsen af Salmonellahandlingsplanen for Konsumæg og Kampagnen mod Vildledende Markedsføring er det primært Veterinær-og Fødevaredirektoratet, der har påtaget sig rollen som varetager af forbrugernes interesser. I Vildledningskampagnen er det sket gennem øget fokus på mærkning, der skal sikre forbrugerne bedre vejledning om, hvilke produkter de køber (Veterinær- og Fødevaredirektoratet, 1999a: 2), og i salmonellahandlingsplanen er det sket gennem et kontrolprogram, der skulle sikre færre syge mennesker. Desuden har det været Fødevareministeriets opfattelse, at landbruget, og ikke forbrugerne, skal betale for salmonellaplanen. Dog med et start tilskud fra staten (Teknologirådet, 1998: 7, 145-146).

Salmonellahandlingsplanen har mødt modstand hos Det Dansk Fjerkræråd, der frygtede, at de mange fordyrende tiltag ville underminere ægproducenternes konkurrenceevne (Teknologirådet, 1998: 125), og Vildledningskampagnen har mødt 
modstand hos producenter og forarbejdningsindustrien, herunder landbruget, fordi mange har fået påbud om at ændre produkters navne eller indpakning (Veterinærog Fødevaredirektoratet, 1999a).

\section{Kvalitetsmærkningsordningen Den Blå Lup}

Arbejdet med det nye kvalitetsmærke startede i 1995, efter at Forbrugerrådet henvendte sig til Henrik Dam Kristensen for at få Landbrugs- og Fiskeriministeriet til at tage initiativ til et statskontrolleret kvalitetsmærke ("Bestået - Men uden udmærkelse", Aktuelt, 16.03.1998). Baggrunden var, at forbrugeme havde svært ved at overskue de mange private kvalitetsmærker på markedet og derfor ikke kunne gennemskue, hvad de betalte ekstra for. Landbrugs- og Fiskeriministeriet udarbejdede herefter et kommissorium og nedsatte i juli 1995 Kvalitetsmærkningsudvalget, der skulle udarbejde et forslag til en kvalitetsmærkning og specificere hvilke parametre, der skulle danne grundlag for ordningen (Veterinærdirektoratet, 1995b).

Udvalget var bredt sammensat af repræsentanter fra de relevante erhverv, forarbejdningsindustrien, detailhandelen og forbrugerne. Således indgik så forskellige organisationer som Dansk Industri, Danske Slagterier, Forbrugerrådet og Foreningen til Dyrenes Beskyttelse i det 28 mand store udvalg (Veterinærdirektoratet, 1995a). I løbet af 1995 og 1996 udarbejdede udvalget Rapport om en frivillig morkningsordning (Veterinærdirektoratet, 1995b) og derefter Koncept til en frivillig kvalitetsmorrkning (Veterinærdirektoratet, 1996a), hvori udvalget fremlagde retningslinjerne for mærket. I første omgang ville udvalget koncentrere sig om svine-, okse- og kalvekød og basere mærket på krav, der har særlig betydning for dyrevelfærd, forbrugertillid og spisekvalitet (Veterinærdirektoratet, 1996a).

Udvalget afholdt efter afgivelse af de to rapporter yderligere tre møder frem til juni 1997, hvor det blev nedlagt efter at have færdiggjort arbejdet (Veterinær- og Fødevaredirektoratet, 1997a). Efterfølgende oprettedes Fødevarekvalitetsudvalget til at administrere og løbende vurdere ordningen. Dette udvalg blev ligesom det foregående bredt sammensat af berørte interesseorganisationer (Veterinær- og Fødevaredirektoratet, 1999c: Bilag B). I marts 1998 kom det første kød med det nye kvalitetsmærke i butikkerne, og Fødevareministeriet har løbende iværksat oplysningskampagner for at gøre mærket kendt blandt forbrugerne ("Kød med statens mærke", Jyllands-Posten, 28.02.1998). Mærket slog dog aldrig rigtigt igennem, og i november 2000 blev det besluttet at droppe Den Blå Lup og nedlægge Fødevarekvalitetsudvalget ("Nyt mærke for kvalitetsmad", Berlingske Tidende, 11.11.2000).

\section{Centrale konflikter}

På grund af udvalgets meget brede sammensætning har der været utallige konflikter undervejs (Andresen, 1998: 558), og det har derfor været nødvendigt at udvælge de mest centrale og betydningsfulde områder for erhvervs- og forbrugeraktøreme til en nærmere analyse. To af de mest omstridte punkter har været, hvor meget ekstra plads dyrene skulle have, og hvorvidt spisekvalitet og censorisk bedømmelse skulle medtages. 
Det Danske Gastronomiske Akademi og Eurotoques havde oprindeligt med støtte fra Forbrugerrådet krævet, at spisekvalitet skulle spille en central rolle for kalve- og oksekød. Dette skulle ske gennem krav til transport, nedfrysning, race, slagtevægt og alder, modning af kød på kroge, kriterier for farve, mørhed og fedtmarmorering og et smagspanel, der skulle godkende kødets smag (Dansk Veterinærtidsskrift, 1996: 674; "Bestået - Men uden udmærkelse", Aktuelt, 16.03.1998). De nævnte krav mødte stor modstand hos slagterierne, landbruget og detailhandelen. De mente kun, at objektive kriterier som transport, race og slagtevægt burde indgå, mens man ikke kunne sige noget generelt om udseende eller smag (Veterinærdirektoratet, 1996a: 22).

Som en følge af uoverensstemmelserne intervenerede Henrik Dam Kristensen derefter i udvalgets arbejde og tilkendegav, at han fortsat ønskede, at smagsbedømmelse af spisekvaliteten skulle indgå som en del af mærket (Veterinærdirektoratet, 1996b: 7), dog kun i form af forbedrede krav til transport, nedfrysning, race, slagtevægt og alder. Kompromiset indeholdt derimod ingen bestemmelser om møming på kroge eller kriterier for farve, mørhed og fedtmarmorering. Dette førte senere til en del kritik fra især Det Danske Gastronomiske Akademi, og efter længere tids utilfredshed med landbruget og slagteriemes indstilling besluttede de at trække sig ud af Fødevarekvalitetsudvalget (Radioavisen, 03.05.2000, kl. 08.00).

Smagsbedømmelse af spisekvaliteten kom altså til at indgå i kravene til kvalitetsmærkningsordningen, men fik ikke den centrale placering, som kokkene havde $\emptyset n$ sket. Landbruget og slagterierne accepterede at medtage det $\mathrm{i}$ formen beskrevet ovenfor, men disse krav var reduceret så kraftigt, at selv landbruget erkender, at spisekvalitet ikke udgør en central del af ordningen (De Danske Slagterier, 2000).

Hvor meget ekstra plads, svin skulle have, var en anden central del af ordningen. Forbrugerrådet og Dyrenes Beskyttelse mente, at svinene skulle have minimum 50 pct. ekstra, og at ordningen skulle tages op til overvejelse hvert år. Landbruget og slagterieme mente, at svinene højest skulle have 20 pct. ekstra, og at ordningen først skulle revideres efter fem år (Veterinærdirektoratet, 1996a: bilag 1: 5-6). Kompromiset blev, at svinene fik 30 pct. ekstra plads, at kravene skulle revideres årligt, hvis der fremkom nye forskningsresultater, og at der blev givet en varslingsperiode på to år ved ændringer (Veterinærdirektoratet, 1997: 5). Desuden lykkedes det Forbrugerrådet at få medtaget et forbud mod brug af pvc holdig emballage fra 01.06.1998 og et forbud mod anvendelse af antibiotiske vækstfremmere på alle svin. Disse krav havde henholdsvis detailhandelen og landbruget plus slagterieme ellers modsat sig tidligere (Veterinærdirektoratet, 1995b: 11; Veterinærdirektoratet, 1996a: bilag 1: 10).

Men Forbrugerrådet og Dyrenes Beskyttelse måtte også opgive en række krav til ordningen eller indgå kompromiser, som de senere har indrømmet, var utilfredsstillende. For eksempel fik dyrene ikke den mængde halm, man havde håbet. Brug af tremmegulve og eldrivstave blev kun begrænset og ikke forbudt, som $\emptyset$ nsket. Haleklipning forblev tilladt om end ikke rutinemæssigt. Krav om adgang til det fri blev ikke en del af ordningen. Fiksering af farende og diegivende søer var fortsat muligt, om end kun i begrænset omfang. Spisekvalitet blev som nævnt 
også næsten sløjfet (Veterinærdirektoratet, 1996a; "Kvalitetsdyr har det ikke godt", Information, 05.03.1998). Særligt forbud mod fiksering af søer havde Dyrenes Beskyttelse kæmpet for, men dette blev ikke en del af ordningen (Foreningen til Dyrenes Beskyttelse, 2000).

Som det ses af ovenstående gennemgang har forbrugerorganisationerne på en række områder været $i$ stand til at opnå aftaler, der var bedre for forbrugerne, end hvad landbrug og slagterier oprindeligt ville acceptere. Generelt må man dog sige, at det er sidstnævnte organisationer, der har haft størst indflydelse på ordningen. Dette illustreres af de udmeldinger, der senere er kommet. Foreningen til Dyrenes Beskyttelse har siden erkendt, at mærket i dets nuværende form ikke sikrer dyrene en tilfredsstillende velfærd. De valgte alligevel at gå med, fordi det var bedre at få en dårlig ordning, der kunne arbejdes videre med, end slet ingen ordning (Foreningen til Dyrenes Beskyttelse, 2000). Således kan svin produceret efter de vedtagne retningslinjer langt fra opnå Dyrenes Beskyttelses eget kvalitetsmærke Det Røde Segl, som de private mærker Eng-Gris (De Grønne Slagtermestre) og Frilandsgris (Favør) har opnået (Foreningen til Dyrenes Beskyttelse, 2000; "Bestået - Men uden udmærkelse", Aktuelt, 16.03.1998). Ydermere har Annette Weber fra Dyrenes Beskyttelse tilkendegivet, at de på en række områder ikke var tilfredse med ordningen, og at der særligt med hensyn til ordningen for svin var mange krav, de ikke kom igennem med (Foreningen til Dyrenes Beskyttelse, 2000). Forbrugerrådet har efterfølgende været mindre kritiske, men har ligeledes fremhævet, at de måtte indgå mange kompromiser undervejs ("Økologer tryner kvalitetsmærke", Jyllands-Posten, 12.03.1998).

Forklaringen på landbrugets og slagteriernes dominerende rolle i denne sag skal findes i deres særlige position. De har haft en slags vetoret, idet det var dem, der skulle producere og forarbejde kødet i henhold til mærket, og uden dem ville der derfor ikke blive nogen ordning. Efterfølgende er de da også de eneste, der har udtrykt ubetinget glæde ved ordningen. Om det opnåede resultat siger Danske Slagterier, at "det er et kompromis, og sådan nogle må man altid være tilfredse med ... Vi har været godt tilfredse med mærket” (De Danske Slagterier, 2000).

\section{Et udvandet kvalitetsmaerke}

Set i lyset af ovenstående analyse støtter denne case teorien om, at landbruget har bevaret deres store indflydelse i sager relateret til Fødevareministeriet i og med, at det er dem, der har fået flest krav igennem til mærket. Omvendt er det ikke nødvendigvis et eksempel på, at Landbrugs- og Fiskeriministeriet ikke har fors $\emptyset \mathrm{gt}$ at opprioritere forbrugerne. Landbrugs- og Fiskeriministeriet har taget Forbrugerrådets ide op til overvejelse, inddraget mange organisationer og ydermere inddraget alle på samme tid. Derfor kunne man også argumentere for, at Landbrugs- og Fiskeriministeriet har fors $\emptyset \mathrm{gt}$ at opprioritere forbrugerinteresser, men ikke er lykkedes med dette, fordi ordningen ikke kunne gennemføres uden landbrugets velvilje, hvilket har givet dem stor magt i denne sag. Dette støttes også af det faktum, at man efter at have opgivet Den Blå Lup nedsatte et nyt mindre udvalg, ledet af kokken Claus Meyer og med deltagelse af fire til seks uafhængige fagfolk, der skulle forsøge at skabe et nyt fødevarekvalitetsmærke ("Nyt mærke for kvalitets- 
mad", Berlingske Tidende, 11.11.2000; "Kvalitetsmærke for mad skal skiftes ud", Politiken, 10.11.2000).

\section{Salmonellahandlingsplanen for konsumæg}

I 1991 iværksatte Det Danske Fjerkræråd den første frivillige handlingsplan mod salmonella i konsumæg (Pedersen, 1996: 10). Antallet af humane salmonellatilfælde, der kunne føres tilbage til konsumæg, fortsatte dog med at stige. Dette fik i 1994 Landbrugs- og Fiskeriministeriet til at gå ind i bekæmpelsen af salmonella, og samme år iværksatte Fjerkrærådet og Ministeriet den første fælles handlingsplan for salmonellabekæmpelse (Statsrevisoreme, 2000: 27).

Med henblik på at iværksætte en udvidet salmonellahandlingsplan gennemførte Landbrugs- og Fiskeriministeriet i januar 1996 en salmonellahøring for at belyse erfaringer og muligheder for bekæmpelse af salmonella (Statens Veterinære Serumlaboratorium, 1996). Dette førte til handlingsplanen for slagtekyllinger og konsumæg, der blev påbegyndt i 1996 (Lovbekendtgørelse nr. 1059-1061 af 09.12.1996; Statsrevisoreme, 2000: 27). Siden er planen løbende blevet justeret, $\mathrm{i}$ forhold til de erfaringer, man har gjort sig undervejs, og senest er planen ved dens oprindelige udløb 1. januar år 2000 blevet forlænget i endnu tre år (Det Danske Fjerkræråd, 2000a). Målene med planen er først og fremmest at sikre, at færre mennesker bliver smittet med salmonella fra fjerkræ (Dansk Veterinartidsskrift, 1998; Teknologirådet, 1998: 7).

\section{Skrap kost for agproducenterne}

Da det er handlingsplanen for konsumæg, der har været de største slagsmål omkring, vil fokus i artiklen være på denne. Gennem de mange konflikter giver handlingsplanen for konsumæg den bedste mulighed for at vurdere, hvem der er blevet tilgodeset. Denne vurdering vil tage udgangspunkt i tre centrale forhandlinger om planens forløb. Det drejer sig om planens iværksættelse i 1996, om planens opstramning i 1998 og om planens forlængelse i år 2000.

På baggrund af erfaringerne fra salmonellahøringen startede Veterinærdirektoratet udarbejdelsen af en ny handlingsplan i samråd med fjerkræbranchen. Det var Veterinærdirektoratet, der stod for udarbejdelsen af selve planen, men Fjerkrærådet deltog jævnligt i møder med direktoratet og blev hørt, inden den endelige bekendtgørelse blev udarbejdet (se for eksempel Landbrugs- og Fiskeriministeriet 1996a, 1996b; Det Danske Fjerkræråd, 1996b).

Den mest radikale ændring i forhold til tidligere planer var, at alle salmonellasmittede dyr nu skulle slås ned. Tidligere havde man kun slået dyr ihjel i toppen af produktionspyramiden, dvs. forældredyrene, men nu skulle alle, også de ægproducerende høns, slås ned, hvis der blev konstateret salmonella (Wegener, 1996: 5). På baggrund af den foregående indsats i toppen af produktionspyramiden mente Veterinærdirektoratet, at tiden nu var inde til at udvide indsatsen (Fødevaredirektoratet, 2000b). Fjerkræbranchen delte ikke denne opfattelse. De mente, at planen var for ambitiøs, og at nedslagtning i alle led var urealistisk at gennemføre (Det Danske Fjerkræråd, 2000b). Det samme argument blev fremført af flere producenter, da planen blev præsenteret for dem på møder rundt omkring i landet 
(DR-dokumentar, 2000). Landbrugs- og Fiskeriministeriet fastholdt sit krav, idet planens mål var at udrydde salmonella på kun tre år, og for at opnå dette måtte der sættes ekstraordinært ind.

Til gengæld blev der ydet fuld erstatning til de besætninger, der blev ramt af salmonella (Det Danske Fjerkræråd, 1996a: 11). Dog indebar planen, at erhvervet selv skulle afholde udgifter til rengøring af stalde i forbindelse med salmonellafund. Dette beløber sig typisk til 90.000-100.000 kroner pr. stald (Fødevaredirektoratet, 2000a). Det Danske Fjerkræråd protesterede også imod Veterinærdirektoratets forslag om, at de selv skulle overtage det fulde ansvar for at bekæmpe salmonella ved planens udløb efter tre år (Det Danske Fjerkræråd, 1996a). De mente, at dette skulle genovervejes i lyset af situationen ved planens udløb. Veterinærdirektoratet fastholdt imidlertid, at det var erhvervet selv, og ikke forbrugerne, der skulle betale for indsatsen efter planens udløb (Landbrugs- og Fiskeriministeriet, 1996b: 5).

Desuden følte Det Danske Fjerkræråd ikke, at Veterinærdirektoratet var lydhør over for deres biologiske og tekniske argumenter omkring planens udformning. Foruden deres argumenter mod at gribe ind i alle fire led i produktionen på én gang gjaldt det for eksempel antallet af salmonellaprøver, producenterne skulle foretage (Det Danske Fjerkræråd, 2000b). Her mente man ikke, at der var fagligt belæg for de hyppige prøvefrekvenser. Til gennemførelse af planen blev der bevilget 188 millioner kroner, hvoraf erhvervet selv bidrog med 30 millioner kroner gennem produktionsafgifter (Akt 441 af 10.09.1996; Statens Jordbrugs- og Fiskeriøkonomiske Institut, 1999: 99). Til at lede planens udformning, afvikling og økonomi nedsattes en styregruppe, der blev bakket op af en teknisk arbejdsgruppe, der skulle vejlede i tekniske spørgsmål. Begge kom til at bestå af repræsentanter fra bådet det offentlige og erhvervet.

Umiddelbart inden planens iværksættelse blev et større hold forældredyr inficeret med salmonella (Fødevaredirektoratet, 2000b). Smitten spredte sig ned gennem produktionspyramiden, og det viste sig hurtigt, at langt flere kyllinger end antaget var smittet. Dette gav problemer. Dels ville man slå en meget stor del af konsumægsektoren ned, hvis man fortsatte, dels kunne man ikke længere garantere salmonellafri erstatningskyllinger, og dels ville de afsatte midler hurtigt slippe op, hvis man fortsatte som hidtil. Producenterne og Det Danske Fjerkræråd hævdede, at dette var præcis, hvad de havde advaret imod, da de modsatte sig en plan, der greb ind i alle fire led af produktionen på en gang (Det Danske Fjerkræråd, 2000b). Veterinærdirektoratet hævdede på den anden side, at det skyldtes smitteopblomstringen umiddelbart inden planens iværksættelse (Fødevaredirektoratet, 2000b).

Situationen tvang Fødevareministeriet til at stille planen i bero i september 1997, mens man overvejede situationen (Statsrevisorerne, 2000: 27). De næste seks måneder overvågede man situationen og koncentrerede indsatsen at få usmittede forældredyr sat ind i toppen af produktionspyramiden ( F $\phi$ devarenvt, 1998: 6). Sideløbende med dette foregik der direkte forhandlinger mellem Det Danske Fjerkræråd og Fødevareministeriet om betingelserne for ændring og videreførelse af planen (Fødevareministeriet, 2000b), og i marts 1998 blev planen genoptaget (Lovbekendtgørelse nr. 147-150 af 02.03.1998). 
På grund af de store udgifter til erstatninger, der havde været under planens første del, måtte man foretage en række justeringer. Fødevareministeriet fastholdt, at dette ikke måtte gå ud over forbrugerbeskyttelsen (Fødevaredirektoratet, 2000b). Derfor blev det besluttet, at kyllinger, der blev konstateret salmonellainficerede, ikke længere skulle slås ned, hvis de allerede vari gang med at producere konsumæg. De fik i stedet lov til at producere færdig, mod at deres æg skulle varmebehandles (Statsrevisorerne, 2000: 28-30). Det Danske Fjerkræråd var principielt for denne ide, men gjorde opmærksom på, at det ville betyde alvorlige økonomiske belastninger for erhvervet, hvis de ikke blev kompenseret for varmebehandlingen (Det Danske Fjerkræråd, 2000b). Dette skyldes, at varmebehandling er relativt dyr, og at æggene efterfølgende ikke kan sælges til butikker, men kun til fødevareindustrien, som betaler en nedsat pris for deres æg. Det lykkedes imidlertid ikke Det Danske Fjerkræråd at sikre erstatning til varmebehandling eller kompensation for den reducerede pris.

I de første led af produktionskæden skulle kyllinger fortsat slås ned, hvis der blev konstateret salmonella, men for at motivere producenter til at søge at undgå salmonella blev selvrisikoen $\varnothing$ get fra 10 pct. til 20 pct. (Fødevareministeriet, 1999: 38). Desuden blev planen udvidet til at omfatte alle typer salmonella og ikke som hidtil kun de to mest udbredte, kravene til rengøring og hygiejne blev opstrammet, og prøvefrekvenserne blev øget (Fødevaredirektoratet, 2000b; Statsrevisorerne, 2000: 29).

Ved udgangen af 1999 udløb planen, men inden da nedsatte man en ad hoc arbejdsgruppe, igen med repræsentanter fra både det offentlige og erhvervet, til at drøfte betingelserme for en fortsættelse af planen, og i februar 2000 blev planen videreført (Fødevaredirektoratet, 2000b). De ca. 60 millioner kroner af bevillingen fra 1996, der endnu ikke var anvendt, overførtes til den nye plan, men ellers fastholdt Fødevareministeriet, at der ikke blev ydet flere penge fra det offentliges side (Landbrugsbladet, 2000). Allerede fra 01.01.2001 overgik udgifterme til overvågning $\mathrm{og}$ rådgivning til erhvervet, $\mathrm{og}$ det er hensigten, at erhvervet skal overtage en stadig større del i takt med, at den oprindelige bevilling slipper op (Fødevaredirektoratet, 1999). Dette var som nævnt aftalt allerede i 1996, men førte alligevel til protester fra branchens side. Der er flere grunde til dette. Dels frygter man, at de ekstra økonomiske omkostninger vil underminere producenternes muligheder for at overleve en salmonellainfektion. Dels mener man, at det vil underminere det danske erhvervs konkurrenceevne, fordi der ikke stilles samme skrappe krav til producenter i andre EU-lande (Det Danske Fjerkræråd, 2000b). De danske producenter får derfor svært ved at konkurrere prismæssigt med ukontrollerede udenlandske æg, som de danske myndigheder ikke kan forbyde importen af på grund af EU's indre marked (Landbrugsbladet, 2000).

\section{Inddragelse, men ikke indflydelse}

Salmonellahandlingsplanen for konsumæg kan ikke hævdes at være udtryk for, at landbruget stadig dikterer Fødevareministeriets politik. Man har indført en meget streng salmonellahandlingsplan, og som beskrevet ovenfor har man på afgørende områder modgået erhvervets ønsker, strammet reglerne kraftigt og senest fastholdt 
sin beslutning om ikke at deltage i finansieringen af salmonellahandlingsplanen ud over den oprindelige bevilling. I stedet viser denne sag, at forbrugerinteresser prioriteres højt.

Planen, der blev iværksat i 1996, sigtede mod at få udryddet salmonella i løbet af tre år og er på den baggrund blevet kaldt verdens strengeste. Da planen løb ind i økonomisk modvind, fastholdt Veterinær- og Fødevaredirektoratet på trods af protester fra Det Danske Fjerkræråd, at målsætningen skulle fastholdes på bekostning af større betaling fra erhvervet, og senest har man ved planens udl $\varnothing b$ fastholdt, at erhvervet skal overtage det fulde ansvar i løbet af de kommende år. Fødevareministeriet har gennem hele planen fastholdt de forbrugerpolitiske målsætninger, nemlig at forbrugerne skal have salmonellafri fødevarer, og at det er erhvervet, der skal betale for dette.

Det er imidlertid ikke vist, at dannelsen af Fødevareministeriet har ændret noget. Planen blev startet inden dannelsen af Fødevareministeriet, den ambitiøse målsætning blev formuleret her, og man fastslog, at erhvervet selv skulle overtage ansvaret for planen. Senere har man justeret planen ud fra de ændrede forudsætninger, men der er ikke noget, der tyder på, at dannelsen af Fødevareministeriet har ændret prioriteringen mellem erhvervets og forbrugernes interesser. Dette bekræftes af både Fødevaredirektoratet (2000b) og Det Danske Fjerkræråd (2000b). For eksempel siger Thorkild Ambrosen fra Det Danske Fjerkræråd, at "Forbrugerbølgen kom allerede inden dannelsen af Fødevareministeriet. Det er snarere forbrugerbølgen, der førte til dannelsen af Fødevareministeriet end omvendt. ... Vi føler, at man gennem hele planen har tilsidesat vores argumenter og ønsker" (Det Danske Fjerkræråd, 2000b).

\section{Vildledningskampagnen}

Ideen til Vildledningskampagnen opstod i 1996 blandt en gruppe embedsmænd i Levnedsmiddelstyrelsen, som dengang hørte under Sundhedsministeriet (Fødevaredirektoratet, 2000a). De havde hørt om Landbrugs- og Fiskeriministeriets arbejde med kvalitetsmærkningsordningen, men frygtede, at det nye mærke ville drukne i mængden af private mærker. Ideen om at sikre forbrugerne en bedre vejledning bifaldt de imidlertid, om end de mente, at det skulle gøres på en anden måde. I stedet for et kvalitetsmærke skulle varerne differentieres gennem en bedre deklaration af deres indhold (Fødevaredirektoratet, 2000a). Levnedsmiddellovens $\$ 23$ forbyder "salg af levnedsmidler under omstændigheder, der er egnet til at vildlede forbrugerne med hensyn til varens oprindelse, fremstillingstidspunkt, beskaffenhed, art, mængde, sammensætning, behandling, egenskaber og virkninger" (Veterinær- og Fødevaredirektoratet, 1997b: 5). De foreslog derfor Sundhedsministeriet at iværksætte en kampagne, der skulle sætte øget fokus på denne del af lovgivningen. Der var imidlertid ikke politisk opbakning til ideen i Sundhedsministeriet, primært fordi det ikke var et tiltag, der direkte vedrørte sundhed (Fødevaredirektoratet, 2000a).

Da Levnedsmiddelstyrelsen i 1997 blev flyttet til Fødevareministeriet, udarbejdede samme gruppe embedsmænd et notat til Departementet $\mathrm{g}$ foreslog at iværksætte kampagnen (Levnedsmiddelstyrelsen, 1997). Henrik Dam Kristensen var 
fra start positiv over for ideen, og det blev besluttet at køre kampagnen. Kampagnen blev døbt "Vildledningskampagnen", fordi den skulle sikre forbrugerne mod vildledende markedsføring. For eksempel skulle der sættes ind mod at kalde sauce for flødesauce, hvis det ikke indeholdt fløde, afbilde solbær på saft, der ikke indeholdt solbær og kalde brød for italiensk, hvis ikke opskriften kunne føres tilbage til Italien (Veterinær- og Fødevaredirektoratet, 1997b: 10-12). Inden kampagnen startede, blev der i foråret og sommeren 1997 afholdt en række møder, hvor planen blev præsenteret for kontrolmyndigheder, brancher og virksomheder. Dette havde dog mere til formål at informere de berørte interesser og opnå deres accept af kampagnen, end det var en reel mulighed for at præge kampagnen. På dette tidspunkt var "facitlisten" for kampagnen allerede udarbejdet (Fødevaredirektoratet, 2000a).

I Veterinær- og Fødevaredirektoratet blev der nedsat en task force til at drøfte forespørgsler vedrørende vildledning, men der blev ikke nedsat udvalg med repræsentanter fra de berørte interesser. Kampagnen udløb oprindeligt ved udgangen af 1998, men det blev besluttet at videreføre den, og i 1999 blev det besluttet at stramme sanktionsmulighederne fra januar 2000 (Veterinær- og Fødevaredirektoratet, 1999a: 2-5). I løbet af kampagnen er der blevet givet over 200 påbud og forbud, og mange producenter har frivilligt ændret deres markedsføring. Blandt andet har man påpeget fejlagtig deklaration, der har eksisteret $i$ mere end 20 år. Alt i alt skønnes det, at der er sket ændringer i mærkning og markedsføring af over 1000 produkter som følge af kampagnen (Clemmensen, 1999: 20-21).

\section{Betydningen af reorganisering}

Kampagnen er et klart eksempel på, at organization matters. Uden overflyttelsen af Levnedsmiddelstyrelsen til Fødevareministeriet og den politiske opbakning til kampagnen i dette ministerium var kampagnen ikke blevet til noget. Ved at samle alle dele af kontrollen med levnedsmidler i samme ministerium opnåede man, at der opstod overensstemmelse mellem styrelsen, der fik ideen, og ministeriet, der skulle bakke kampagnen op politisk. Inden reorganiseringen havde man den specielle situation, at Sundhedsministeriet afviste Levnedsmiddelstyrelsens ide, fordi den ikke rigtigt hørte ind under deres resort. Det var dog ikke reorganiseringen alene, der gjorde det. Uden en reel politisk vilje til at sætte handling bag ordene og iværksætte en kampagne, der skulle sætte forbrugerne i centrum på bekostning af industrien, var kampagnen næppe blevet til noget.

Denne case understøtter klart hypotesen om, at forbrugerinteresser er blevet opprioriteret efter dannelsen af Fødevareministeriet, og modgår hypotesen om, at reorganiseringer blot er et politisk spil uden nævneværdig effekt, og at det landbrugsdominerede netværk omkring Fødevareministeriet ville fortsætte uforandret.

\section{Konklusion}

På baggrund af analysen kan hypotese et delvist bekræftes. Dannelsen af Fødevareministeriet har i mindst én sag ført til en opprioritering af forbrugerinteresser. Reorganiseringen af Levnedsmiddelkontrollen og den efterfølgende dannelse af Fødevaredirektoratet samlede kontrollen med fødevarer fra "jord til bord" og mulig- 
gjorde derved Vildledningskampagnen, som en gruppe embedsmænd i Levnedsmiddelstyrelsen længe havde haft $\mathrm{i}$ tankerne. De organisatoriske ændringer i forbindelse med dannelsen af Fødevareministeriet har altså haft en betydning.

Der kan imidlertid ikke spores ændring i den politiske opbakning til forbrugerne i ministeriet. Her viser sagerne om kvalitetsmærket og salmonellahandlingsplanen for konsumæg, at forbrugerinteresser allerede inden dannelsen af Fødevareministeriet var prioriteret højt. I forbindelse med salmonellahandlingsplanen tog man allerede inden dannelsen af Fødevareministeriet et par gevaldige opgør med erhvervet, og i sagen om kvalitetsmærket kunne landbruget ganske vist blokere forbrugerinteresserne, men det er omvendt også vist, at den politiske opbakning til forbrugerrepræsentanterne ikke manglede. Som Annette Weber fra Dyrenes Beskyttelse sagde: "efter Henrik Dam Kristensens udnævnelse til minister er vi ofte blevet inddraget i relevante sager og oplever generelt, at ministeriet lytter til vores argumenter"(Foreningen til Dyrenes Beskyttelse, 2000). Dette antyder, at den politiske opbakning til forbrugerne kom med Henrik Dam Kristensens udnævnelse til Landbrugs- og Fiskeriminister og ikke hans titelskift til Fødevareminister. I hvert tilfælde kan det konstateres, at forbrugerorienteringen kom inden dannelsen af Fødevareministeriet.

I forlængelse af dette må hypotese to afvises. Afvisningen skyldes dog ikke direkte Fødevareministeriets dannelse. I sager vedrørende forbrugerpolitik har landbruget ikke formået at bevare sin store indflydelse i Fødevareministeriet. Ganske vist gav deres særlige position i relation til kvalitetsmærket dem stor indflydelse på dette mærke, men i salmonellahandlingsplanen og Vildledningskampagnen har deres indflydelse været begrænset. I sidstnævnte grænsende til ikke eksisterende. I de analyserede cases har der været tale om mere end blot symbolpolitik, og ingen af sagerne bærer præg af at være behandlet af et lukket politikfællesskab med fælles værdier og et snævert syn på løsningsmuligheder. Til gengæld ser navneskiftet til Fødevareministeriet ud til at tjene symbolske formål, idet Ministeriet dermed fik et navn, der var mere dækkende for den linje, man allerede havde lagt $\mathrm{i}$ forbrugerpolitiske spørgsmål.

Analysen kan desuden tjene som bidrag til debatten om, hvorvidt korporatisme i Danmark er under forandring. I Magtens Organisering (Blom-Hansen og Daugbjerg, 1999) gennemgås de korporative strukturer inden for en række af de vigtigste sektorer i Danmark, og i langt de fleste sektorer er der klare tegn på, at disse er under forandring. Analyser har vist, at inddragelse af interesseorganisationer gennem råd, nævn og udvalg toppede omkring 1980 (Christiansen og Sidenius, 1995, 1999; Christensen og Christiansen, 1997: 73-77). Der er imidlertid ikke nødvendigvis nogen sammenhæng mellem tilstedeværelse og indflydelse (Christiansen og Sidenius, 1999: 34). For at vurdere denne sammenhæng er det nødvendigt at kigge nærmere på de enkelte områder. En række af denne type analyser viser, at organisationerne sidder længere fra den politiske proces end tidligere (Nørgaard, 1999; Sidenius 1999; Jensen 1999; Blom-Hansen og Daugbjerg, 1999: 208-209).

De tre cases, der har været inddraget her, er endnu et eksempel på, at inddragelsen af interesseorganisationer i dag sker på en mere fleksibel måde, end hvad man tidligere har oplevet. Arbejdet med Den Blå Lup antyder, at man i forbrugerpolitiske 
spørgsmål allerede inden dannelsen af Fødevareministeriet har forsøgt at frigøre sig fra det tætte politikfællesskab ved at inddrage mange aktører og derigennem mindske afhængigheden af landbruget, når det gælder forbrugerpolitiske spørgsmål. Salmonellahandlingsplanen vidner om, at de traditionelle interesseorganisationer og samspilsformer ikke er blevet irrelevante. Det var en relativ lille gruppe, der blev inddraget i planens udarbejdelse, der blev afholdt høring forud for planens iværksættelse, og planen blev clearet med de berørte interesser. Man fulgte ganske vidst ikke erhvervets anbefalinger, men alle de traditionelle normer for inddragelse af interesseorganisationer blev overholdt.

Vildledningskampagnen er, som Den Blå Lup, et eksempel på, at korporatisme i Danmark tilsyneladende er under forandring. Eksemplet er lidt anderledes end de traditionelle sager i Fødevareministeriet, idet der ikke har været behov for at udarbejde nye love eller regler, det har ikke været nødvendigt med ekspertbistand fra organisationerne, og man har ikke været afhængig af interesseorganisationer til at hjælpe med at implementere reglerne. Det er ellers netop i disse situationer, at interesseorganisationerne ofte har mulighed for at opnå indflydelse. Men i dette tilfælde har Fødevareministeriet selv kunnet implementere den skærpede tolkning af levnedsmiddelloven. Forbigåelsen af interesseorganisationeme har derfor været relativ omkostningsfri sammenlignet med mange andre sager. Hvor omstændighederne omkring arbejdet med Den Blå Lup gav landbruget stor indflydelse, må man omvendt sige, at industrien, og derved også landbruget, har stået svagt $\mathrm{i}$ denne situation, og at Fødevareministeriet har udnyttet dette til at køre kampagnen alene uden at inddrage de berørte interesser. Afhængigheden af interesseorganisationer, og dermed deres indflydelse, ser således ud til at variere afhængigt af sagens karakter.

Således har man valgt tre vidt forskellige måder at håndtere relationerne til interesseorganisationerne på. I Vildledningskampagnen blev de slet ikke inddraget, $\mathrm{i}$ forberedelsen af kvalitetsmærket nedsatte man et 28 mand stort udvalg, og i salmonellahandlingsplanen fulgte man mere traditionelle spilleregler, med inddragelse af en snæver kreds af aktører. Ud fra kun tre sager er det naturligvis svært at udpege en tendens, men måske følges det traditionelle mønster, hvor man er afhængig af ekspertbistand fra organisationerne, mens man vælger løsninger, man finder passende $\mathrm{i}$ den givne situation, hvor interesseorganisationernes viden er mindre afgørende. I forlængelse af dette må de fundne samspilsrelationer siges at støtte Martin Smiths betragtninger vedrørende forholdet mellem ministerium og omgivelser. De tre cases har vist, at det i sidste ende er ministeriet selv, der skaber netværket, kontrollerer adgangen til netværket, skaber spillereglerne i netværket, og har autonomi til at bryde det. Dog er ministeriets valgmuligheder i nogle tilfælde ganske få.

Et spørgsmål, der melder sig på baggrund af denne konklusion, er, om forbrugerinteresser alene er blevet opprioriteret $\mathrm{i}$ sager, der er mindre betydningsfulde for landbruget, hvorimod landbruget stadig har bevaret sin magt i de vigtige sager. Dette syntes dog ikke at være tilfældet. Skulle man vurdere, hvilken af de tre sager, der har været vigtigst for landbruget, må det være salmonellahandlingsplanen, hvor ægbranchens konkurrenceevne har været truet af de mange fordyrende tiltag. 
I denne sag har landbruget imidlertid heller ikke kunnet bevare sin indflydelse. Dette antyder, at konklusionerne er gyldige generelt for forbrugerpolitiske spørgsmål, og ikke kun for mindre betydningsfulde sager.

Et andet spørgsmål er, hvorvidt øget forbrugerindflydelse på de forbrugerpolitiske beslutningerne, også reelt er kommet forbrugerne til gode. I sagen om kvalitetsmærket synes det oplagt, at forbrugerinteresser kun blev tilgodeset $\mathbf{i}$ begrænset omfang, fordi kravene til kvalitetsmærket blev udvandet. Til gengæld opnåede forbrugerne en reel fordel ved Vildledningskampagnen, fordi der skete ændringer i mærkning og markedsføring af over 1000 produkter som følge af kampagnen.

I salmonellahandlingsplanen er sagen knap så enkel. Målet med planen var færre syge mennesker. Problemet for de danske producenter er som næunt, at de belastes alvorligt af den danske handlingsplan, og at deres udenlandske konkurrenter ikke er underlagt samme strenge regler. Dette er angiveligt den primære grund til, at den danske produktion af æg er faldet fra 62,3 mio. kilo i 1996 til 50,8 mio. kilo i 1999 (Det Danske Fjerkræråd, 2000a: 17-19). Tilsvarende er importen af udenlandske æg steget fra ca. 10 mio. kilo i 1996 til ca. 26 mio. kilo i 1999. Importen i pct. af det hjemlige forbrug er steget fra ca. 19 pct. i 1996 til 42,5 pct. i 1999. Det paradoksale er, at vi på grund af EU's Indre Marked ikke kan stille samme krav til de udenlandske æg, som vi stiller til danske æg. Salmonellahandlingsplanen kan derfor på lang sigt bevirke, at den danske produktion svinder kraftigt på grund af de økonomiske omkostninger forbundet med salmonellahandlingsplanen, og afløses af import af æg, vi ikke må kontrollere for salmonella.

Foreløbigt ser planen dog ud til at leve op til målet. Mennesker smittet med salmonellatypen Enteritidis som primært findes $\mathrm{i} æ g$, er faldet fra ca. $38.000 \mathrm{i}$ 1997 til ca. 20.000 i 1999 (Dansk Zoonosecenter, 2000). Dette er dog stadig flere end årene før, planen blev iværksat, og spørgsmålet er, om salmonellahandlingsplanen for konsumæg vil vedblive med at komme forbrugerne til gode, hvis importen af udenlandske æg fortsætter med at stige?

\section{Noter}

1. Mange dokumenter fra Internettet har ikke fortløbende sidenummerering, men starter forfra med side 1 ved et nyt kapitel. Således henviser kap. 3: I til side $1 \mathrm{i}$ kapitel 3 .

2. De vigtigste kilder til artiklen er mødereferater, bekendtgørelser, notater, rapporter og andet skriftligt materiale. Da der ofte er der tale om teknisk set relativt komplicerede sager, er aktørernes egne vurderinger af sagerne desuden medtaget. Dette er dels gjort gennem artikler og udtalelser i tidsskrifter og dagblade, og dels gennem interviews med centrale repræsentanter fra de forskellige parter. Interviewene har desuden haft til formål at belyse det mere uformelle samspil i de udvalgte cases.

Således er en repræsentant for forbrugerinteresser og en fra landbruget blevet interviewet $\mathrm{i}$ sagerne om salmonellaproblemerne og kvalitetsmærket, mens der kun er blevet interviewet én person fra Fødevareministeriet i sagen om vildledende markedsføring, idet interesseorganisationer ikke har været inddraget. De interviewede personer er så vidt muligt blevet stillet enslydende spørgsmål om, hvordan de var inddraget i det forberedende arbejde (Fødevaredirektoratet blev spurgt om hvem, de havde inddraget), hvilke krav de stillede, om kravene blev medtaget, og om de efterfølgende har været tilfredse. Oplysningerne er blevet brugt i artiklen med varsomhed, idet de interviewede alle har været parter i sagen. Deres vurderinger kan derfor have været 
farvet af personlige og/eller professionelle forhold. Oplysningerne er i videst muligt omfang blevet tjekket med modparten, mødereferater, rapporter eller lignende.

3. Landbruget og slagterierne har været repræsenteret ved Danske Slagterier, Kødbranchens Fællesråd, Det Danske Fjerkræråd, Dansk Erhvervsgartnerforening, Dansk Familielandbrug, De Danske Landboforeninger og Dansk Erhvervsjordbrug. Der vil ikke blive skelnet mellem disse, da de igennem hele forløbet har fremført stort set identiske krav (Veterinærdirektoratet, 1996a).

\section{Litteratur}

Aktuelt.

Akt 441 af 10,09.1996 om iværksættelse af en 3-årig handlingsplan til bekæmpelse af Salmonella i slagtekyllinger og konsumæg.

Andresen, Karin (1998). “Kvalitetsmærket - en langsom men nødvendig ordning”, Dansk veterinartidsskrift, 81. årgang, nr. 15, pp. 558-559.

Berlingske Tidende.

Blom-Hansen, Jens og Carsten Daugbjerg (red.)(1999). Magtens Organisering, Århus: Systime.

Buksti, Jacob A. (1983). Et enigt landbrug? Landbrugets organisationsforhold - specialisering, konkurrence og politisk indflydelse, Århus: Institut for Statskundskab, Aarhus Universitet.

Christensen, Jørgen Grønnegård og Peter Munk Christiansen (1997). Forvaltning og omgivelser, Herning: Systime

Christensen, Tom (1987). "How to Succeed in Reorganizing: The Case of the Norwegian Health Administration", Scandinavian Political Studies, Vol. 10, No. 1, pp. 61-77.

Christiansen, Peter Munk og Niels Chr. Sidenius (1995). “Korporatisme på retur?”, Politica, 27. årgang, nr. 4, pp. 436-449.

Christiansen, Peter Munk og Niels Chr. Sidenius (1999). "Venner for altid? Samspillet mellem centraladministrationen og interesseorganisationerne", pp. 21-35 i Jens Blom-Hansen og Carsten Daugbjerg (red.), Magtens Organisering, Århus: Systime.

Clemmensen, Finn (1999). Kontrollen med vildledende markning, Noter fra foredrag i Levnedsmiddelselskabet, 12.10.

Dansk Veterinartidsskrift (1996). “Ministeren får sit stempel ", 79. årgang, nr. 15, pp. 165-166.

Dansk Veterinartidsskrift (1998). "Fødevareministeriets kvalitetsmærkningsordning", 81 . årgang, nr. 5, pp. 165-166.

Dansk Zoonosecenter (2000). Salmonella-infektioner hos mennesker 1980-1999, http//www.dzc.dk/ gsbh2.htm

Daugbjerg, Carsten (1999). “Landbrugspolitik: Stabilitet eller forandring?”, pp. 107-126i Jens BlomHansen og Carsten Daugbjerg (red.), Magtens Organisering, Århus: Systime.

De Danske Slagterier (2000). Telefoninterview med Direktør Erik Bisgård Madsen, 14.06.

Det Danske Fjerkræråd (1996a). Vedr. udkast til bekendtgørelse om bekampelse af salmonella $i$ fjerkra, Veterinærdirektoratet, journal nr. 2a 10-123-0-27.

Det Danske Fjerkræråd (1996b). Vedr. Den danske plan til bekampelse af sulmonella i slagtekyllinger og konsumag, Veterinærdirektoratet, journal nr. 2a 57-12-0-17.

Det Danske Fjerkræråd (2000a). Beretning 2000. Slagelse: Slagelse Tryk A/S.

Det Danske Fjerkræråd (2000b). Telefoninterview med Afdelingschef Thorkild Ambrosen, 09.05. og 15.06.

DR-Dokumentar (2000). “Ministerens Syge Plan”, Danmarks Radio, 24.05.

Egebjerg, Morten (1984). Organisationsutformning i Offentlig Virksomhet. Otta: Aschehoug.

Foreningen til Dyrenes Beskyttelse (2000). Telefoninterview med Dyrlæge Annette Weber, 13.06.

Fødevaredirektoratet (1999). Notat om det tekniskelфkonomiske grundlag for forbedring af bekampelse og forbrugerbeskyttelse $i$ en tidsbegranset videreførelse af Salmonellahandlingsplanen for Fjerkra, journal nr. 2a 57-12-0.

Fødevaredirektoratet (2000a). Telefoninterview med kontorchef i 5. afd. Finn Clemmensen, 10.05. 
Fødevaredirektoratet (2000b). Telefoninterview med projektchef for salmonellahandlingsplanen Søren Bach Rasmussen, 14.06.

Fødevareministeriet (1998). Fødevareministeriets årsrapport 1997. Politik, Produktion og forbrug, http://www.fvm.dk/publikat/Aarbog97/html97.htm.

Fødevareministeriet (1999). Fødevareministeriets årsrapport 1998. Politik, Produktion og forbrug, København: Ministeriet for Fødevarer, Landbrug og Fiskeri.

Fødevarenyt (1998). “Færre æg er smittet med salmonella", 11. årgang, nr. 2, pp. 6-7.

Information.

Jensen, Lotte (1999). “Boligpolitik: Den organiserede boligbevægelse og institutionaliseringen af den boligpolitiske forestilling”, pp. 84-106 i Jens Blom-Hansen og Carsten Daugbjerg (red.), Magtens Organisering, Århus: Systime.

Just, Flemming og Knut Omholt (1984). Samspillet mellem staten, landbrugsorganisationerne og landbrugskooperationen, Esbjerg: Sydjysk Universitetsforlag.

Jyllands-Posten.

Kristensen, Henrik Dam (1997). “Fødevareministeriet - slagmark eller samarbejdsforum?”, Andelsbladet, årgang 98, nr. 5, pp. 100-101.

Landbrugs- og Fiskeriministeriet (1996a). 2a 57-12-0-15 - opfølgning på møde d. 14.02.1996, Veterinærdirektoratet, journal nr. 96-8100-6.

Landbrugs- og Fiskeriministeriet (1996b). 2a 57-12-0-16-vedr. køreplanfor planen til bekampelse af salmonella $i$ slagtekyllinger og konsumag, Veterinærdirektoratet, journal nr. 96-8100-6.

Landbrugsbladet (2000). "Salmonellaplan til landbruget", årgang 45, nr. 8, p. 14.

Levnedsmiddelstyrelsen (1997). Notat om landsdakkende kampagne om vildledning, 07.02., journal nr. 521.1203-0002

Lovbekendtgørelse nr. 1059 af 09.12.1996.

Lovbekendtgørelse nr. 1060 af 09.12.1996.

Lovbekendtgørelse nr. 1061 af 09.12.1996.

Lovbekendtgørelse nr. 147 af 02.03.1998.

Lovbekendtgørelse nr. 148 af 02.03.1998.

Lovbekendtgørelse nr. 149 af 02.03.1998.

Lovbekendtgørelse nr. 150 af 02.03.1998.

March, James G. and Johan P. Olsen (1983). "Organizing Political Life: What Administrative Reorganization Tells Us About Government”, The American Political Science Review, Vol. 77, No. 2, pp. 281-296.

Nørgaard, Asbjørn S. (1999). “Arbejdsmarkedspolitik:korporatisme til alle tider og alle sider”, pp. 36-60 Blom-Hansen, Jens og Carsten Daugbjerg (red.), Magtens Organisering, Århus: Systime.

Pedersen, Knud Børge (1996). "Hvad kan der gøres i Danmark", Statens Veterinære Serumlaboratorium, Landbrugs og Fiskeriministeriets salmonella-høring den 11. januar 1996, København: Statens Veterinære Serumlaboratorium.

Politiken.

Regeringen (1998). Fødevaresikkerhed - Hovedrapport. Danmark som Foregangsland København: Regeringen.

Rhodes, R.A.W and David Marsh (1992). "New Directions in the Study of Policy Networks", European Journal of Political Research, Vol. 21, No. 1-2, pp. 181-205

Salamon, Lester (1981). "The Question of Goals", pp. 58-84 in Peter Szanton (ed.), Federal Reorganization: What Have We Learned?, Chatham NJ: Chatham.

Scharpf, Fritz W. (1986). "Policy Failure and Institutional Reform: Why Should Form Follow Function?”, International Social Science journal, Vol. 38, No. 2, pp. 179-190.

Scharpf, Fritz W. (1977). "Does Organization Matter? Task, Structure and Interaction in the Ministerial Bureaucracy", Organization and Administrative Sciences, No. 8, pp. 149-168.

Sidenius, Niels Chr. (1999). "Industripolitik: 'Business as Usual'?”, pp. 61-83 i Jens Blom-Hansen og Carsten Daugbjerg (red.), Magtens Organisering, Århus: Systime. 
Smith, Martin J. (1993). Pressure, Power and Policy. State Autonomy and Policy Networks in Britain and the United States, New York: Harvester Wheatsheaf.

Statens Jordbrugs- og Fiskeriøkonomiske institut (1999). Salmonella i slagtekyllinge produktionen, rapport nummer 105, København: Statens Jordbrugs- og Fiskeriøkonomiske Institut.

Statens Veterinære Serumlaboratorium (1996) Landbrugs og Fiskeriministeriets salmonella-høring den 11. januar 1996, København: Statens Veterinære Serumlaboratorium.

Statsrevisorerne (2000). Beretning om statens bekampelse af Salmonella, København: Schultz.

Teknologirådet (1998). Salmonella - resume og udskrift af høring i Folketinget d. 11 november 1998, København: Teknologirådet.

Veterinærdirektoratet (1995a). Referat af 1. møde den 10. august $1995 \mathrm{i}$ udvalget til drøftelse af en kvalitetsmaerkningsordning, journal nr. DI 2.4202-49/95.

Veterinærdirektoratet (1995b). Rapport om en frivillig kvalitetsmaerkningsordning, Frederiksberg: Veterinærdirektoratet.

Veterinærdirektoratet (1996a). Koncept til en frivillig kvalitetsmarkningsordning, Frederiksberg: Veterinærdirektoratet

Veterinærdirektoratet (1996b). Referat af 13. møde den 25. oktober i udvalget til drøftelse af en frivillig kvalitetsmaerkningsordning, journal nr. DI 2.4202.282/96.

Veterinærdirektoratet (1997). Referat af 14. mødei kvalitetsmaerkningsudvalget den 8. april 1997. journal nr. DI 4202-282/96.

Veterinær- og Fødevaredirektoratet (1997a). Referat af 15. møde i kvalitetsmarkningsudvalget den 20. juni 1997, journal nr. DI 4202-287-0-314

Veterinær- og Fødevaredirektoratet (1997b). Vildledning - En vejledning, Søborg: Veterinær- og Fødevaredirektoratet.

Veterinær- og Fødevaredirektoratet (1999a). Rapport om kampagnen mod vildledning, http:// www.vfd.dk/publikationer/

Veterinær- og Fødevaredirektoratet (1999b). Virksomhedsregnskab 1998, http://www.vfd.dk/publikationer/

Veterinær- og Fødevaredirektoratet (1999c). Årsberetning for Kvalitetsmarkningsordningen 1998 1999, http://www.vfd.dk/publikationer/

Wegener, Henrik (1996). "Status for salmonella-situationen i Danmark", Statens Veterinære Serumlaboratorium, Landbrugs og Fiskeriministeriets salmonella-høring den 11. januar 1996, København: Statens Veterinære Serumlaboratorium.

Wilson, James Q. (ed.) (1980). The Politics of Regulation, New York: Basic Books.

Winter, Søren (1987). "Reorganisering og modernisering - En introduktion”, Politica, 19. årgang, nr. 4, pp. 374-384.

Winter, Søren (1994). Implementering og effektivitet, Herning: Systime. 